\title{
ДО ПИТАННЯ СТИЛІСТИЧНОГО МАРКУВАННЯ ЛЕКСИКИ В ЕЛЕКТРОННИХ СЛОВНИКАХ УКРАЇНСЬКОЇ МОВИ
}

\footnotetext{
Сінкевич Н. М. До питання стилістичного маркування лексики в електронних словниках української мови.

У статті розглядаються особливості тлумачення та принципи виділення слів, віднесених до книжного та розмовного стилів в електронних словниках сучасної української мови.

Ключові слова: електронний словник, позначка, розмовний стиль, книжний стиль.

Синкевич Н. М. К вопросу о стилистическом маркировании лексики в электронных словарях украинского языка

В статье рассматриваются особенности толкования и принципы выделения слов, отнесенных к книжному и разговорному стилям в электронных словарях современного украинского языка.

Ключевые слова: электронный словарь, помета, разговорный стиль, книжный стиль.

Sinkevych N. M. To the issue of stylistic marking of vocabulary in ukrainian electronic lexicography

The article deals with the peculiarities of explanation and principles of division of words referred as colloquial or pedantic style in electronic dictionaries of Modern Ukrainian.

Key words: electronic dictionary, mark, colloquial style, pedantic style.
}

Словникова справа, або лексикографія, має на Україні давні й славні традиції. Перший словник було створено ще наприкінці XVI ст. А виданий у Києві у 1627 р. словник Памва Беринди, у якому слова старослов'янської мови перекладалися на тогочасну книжну українську мову, здобув загальне визнання не тільки на Україні і в Росії, але також у Польщі та Молдавії.

Першим тлумачним словником сучасної української мови (він одночасно $\epsilon$ й перекладним) слід вважати «Словарь української мови» у 4-х томах за редакцією Б. Грінченка (К., 1907-1909; останнє видання 1996-1997) - видатна пам'ятка української лексикографії. На даний час існують такі тлумачні словники української мови: «Словник української мови» АН в 11 томах (К., 1970-1980), «Новий словник української мови» у 4 томах В. Яременка й О. Сліпушко (К., 1998), «Короткий тлумачний словник української мови» за редакцією Л.Л. Гумецької (К., 1979; друге видання за редакцією Д. Г. Гринчишина, 1988).

Розвинені лексикографії світу налічують сотні різних типів словників. Не маючи можливостей для проходження того шляху, який пройшла світова лексикографія, Україна була змушена розвивати свої власні підходи до лексикографічної справи в умовах дефіциту історичного часу. Зазначена обставина зумовила необхідність розвитку та впровадження інтенсивних, форсованих методів лексикографування. Ця діяльність набула концентрованого вигляду у працях Українського мовноінформаційного фонду НАН України, де було розроблено базові комп'ютерні технології лексикографування, організовано укладання та випуск серії академічних словників нового покоління - «Словники України», що зрештою дозволило сформулювати концепцію Національної 
словникової бази України і фактично створити іiі. Наявність енциклопедій та словників на електронних носіях - вважається одним із показників інтелектуального рівня нації.

Як відомо 3 теорії, об єктом лексикографування (тобто лексикографічного, словникового опису) можуть (і повинні) виступати мовні одиниці всіх рівнів та будь-які мовні відношення. Сказане визначає необхідність лексикографічного опису якомога ширшого кола мовних явищ. У такий спосіб в Національній словниковій базі повинен бути представлений повний набір різного роду та характеру словників. Окрім орфографічних (кодифікують правописні норми) та орфоепічних (кодифікують літературну вимову та наголос), у НСБ представлені словники синонімів, антонімів, фразеологізмів, еквівалентів слова, стійких словосполучень, різноаспектні граматичні, морфемні, словотвірні, тлумачні, семантичні, синтаксичні, етимологічні, історичні, лінгвогеографічні, галузеві термінологічні, дво- та багатомовні словники.

3 появою комп'ютерної техніки укладачі програмного забезпечення створили новий тип словників - електронний словник. Такий тип словника - абсолютно нове слово в історії лексикографії, яке позначилося новою якісною сходинкою у його розвитку. Саме зараз електронні словники вийшли з тіні паперових і стають самостійними побудовами.

Нині видання словників здійснює Національна академія наук України, відповідно до затвердженої президентом України ще 7 серпня 1999 р. програми «Словники України». А точніше, один із ії підрозділів Український мовно-інформаційний фонд НАН України. I словники, що виходять у цій серії (це видання НАН) вважаються академічними, тобто еталонними. У серію «Словники України» входять, зокрема, двотомний «Словник синонімів української мови», нове видання «Орфографічного словника української мови». На увагу також заслуговує ціла серія двомовних словників. Програмою «Словники України», окрім традиційних, тобто виданих на папері, передбачалося і створення їх електронного відповідника для інформаційних комп'ютерних систем. А тому ще в кінці 2001 p. тиражем 30 тисяч примірників появився електронний словник української мови. Це - інтегрована лексикографічна система «Словники України», яка об’єднувала п'ять словників: орфографічний, орфоепічний, синонімічний, антонімічний та фразеологічний, а також функцію словозміни. Цю фундаментальну працю було присвячено 10-річчю незалежності України. Про іiі фундаментальність наглядно говорить хоча б той факт, що коли роздрукувати на папері усю інформацію, яка $є$ на диску, то це зайняло б сорок тисяч сторінок, або 40 словників по 1000 сторінок кожний. За допомогою системи «Словники України» користувач може дізнатися про написання, наголошення, вимову близько 152 тисяч слів української літературної мови, а також одержати повну інформацію про відмінювання 
цих слів в усіх граматичних значеннях (відмінках, числах, особах тощо). Система «Словники України» укладена на основі сучасних академічних словників української мови за допомогою словозмінної класифікації та комп'ютерних програм, розроблених фахівцями Українського мовноінформаційного фонду. Авторами цього електронного словника $\epsilon$ В. Широков, І. Шевченко, О. Рабулець, О. Костишин, М. Пещак.

Електронні словники мають ряд переконливих і суттєвих переваг порівняно зі словниками традиційними. Сдиним їх недоліком є прикутість до персонального комп'ютера та, відповідно, обмежений доступ. Однак цей недолік невдовзі буде усунутий, якщо не цілком, то примаймні більшою мірою завдяки зростанню комп'ютеризації та, у тому числі, більшої доступності переносних комп’ютерів типу Laptop та КПК.

Традиційно мінімальною одиницею доступу вважається лексема (заголовок словникової статті): необхідно прочитати всю статтю, щоб визначити, чи міститься в ній відповідь на ваш запит. Для багатотомних словників це становить серйозну проблему. Користувач волів би, щоб словник максимально локалізував релевантну інформацію. При цьому не йдеться про автоматичний вибір перекладного еквівалента (якщо ми говоримо про перекладний словник) або тлумачення одного 3 можливих значень слова. Специфіка словникової доповіді полягає у досить різнобічній інформації про слово або словосполучення, а не просто перекладну відповідність, передбачає активний вибір користувача 3 декількох можливих добре обгрунтованих альтернатив.

Метою нашого дослідження $є$ аналіз лексикографічного представлення стилістично маркованої лексики. Як відомо, склад лексики сучасної української мови є стилістично неоднорідним. Залежно від сфери спілкування, мети висловлювання, мовленнєвого рівня співрозмовника ми обираємо різнорівневі мовні засоби, найбільш придатні для конкретної ситуації. Кожен із функціональних стилів характеризується особливостями на всіх рівнях мови - лексичному, морфологічному, синтаксичному тощо. Найяскравіше стилістична диференціація мовних засобів виявляється на рівні лексики. Залежно від сфери використання прийнято виділяти дві групи слів: 1) лексика стилістично нейтральна, чи міжстильова; 2) лексика стилістично маркована («позначена»). Остання поділяється, у свою чергу, на книжну (наукову, ділову, газетно-публіцистичну) і розмовну.

У «Словниках України» стилістично маркована лексика одержує різноманітне висвітлення. По-перше, на диску представлено електронний варіант «Великого тлумачного словника української мови», де існує розгалужена система позначок стилістично маркованої лексики. По-друге, в цій лексикографічній системі існує і багато інших словників: це словники різних галузей наукової лексики, словник іншомовних слів, жаргону, арго тощо.

Поетична лексика вживається лише в художньому стилі, має здебільшого урочисте, піднесене забарвлення. Сюди великою мірою 
належить лексика застаріла, зокрема старослов'янізми, слова, що передають емоційне сприйняття навколишньої дійсності, душевного стану автора. так, електронний словник епітетів української мови дає такі епітети до слова «дзвін»: бісерний, дрижачий, замогильний, кришталевий (всього 49 одиниць). Користуючись тим же диском, можна за лічені хвилини знайти у тлумачних словниках визначення необхідних користувачеві поетичних одиниць.

Іншим різновидом стилістично маркованої лексики $\epsilon$ розмовна лексика До розмовної лексики належать слова, які вживаються в усному невимушеному спілкуванні. Вони не можуть використовуватись у діловому й науковому стилях, включаючи й усі іï усні жанри (лекція, доповідь, виступ). У художньому й публіцистичному стилях ця лексика створює колорит розмовного мовлення.

Порівняно 3 нейтральною лексикою розмовна має стилістичне забарвлення неофіційності, інколи зниженості: авжеж, аніякісіньки, анумо, aнуте. Багато розмовних слів не лише називають предмет, явище тощо, а й дають йому експресивно-емоційну оцінку - позитивну чи негативну. Дослідження паперових та електронних словників свідчить про те, що окремі спеціалізовані словники частково пересікаються за змістом 3 основним тлумачним словником, але частина їх словникового складу не збігається. Так, ми виділили приблизно 60 слів на букву А з позначкою «розм.» у Великому тлумачному словнику і порівняли їх склад зі словами на цю ж букву в електронному словнику сленгу. Виявилося, що збігається лише одне слово «аварійка». Інші 35 слів у тлумачному словнику не представлені.

Сказане вище дозволяє нам зробити висновок про те, що сукупність електронних словників, які представлено на диску «Словники України» не $є$ штучною, а $є$ взаємозалежною та іiі окремі елементи взаємно збагачують один одного.

1. Левицький М. Українські електронні словники - це вже реальність / М. Левицький // Наше слово. - № 13. -30 березня 2003 p.

2. Широков В.А. Інформаційна теорія лексикографічних систем / В. А. Широков. - К.: Довіра, 1998. 